\title{
Get Rid of Water Pollutants Using Porcelain Filter Made From Local Materials
}

\author{
Sanaa Abdulrazaq Jassim ${ }^{1}$ \\ ${ }^{1}$ (Lecturer/ Dept. of Surveying Technic, Technical Institute of Babylon/Iraq)
}

\begin{abstract}
Raw materials from some mines from the Iraqi Westren Desert were used to manufacture tap water porcelain filter. They were Montmorolinite clays, Sand, Limestone, and remnants of the membership. These materials were cleaned dried grind and sieved to the required size then several homogenous mixtures were prepaired using different amounts of the raw materials.

Filter test samples were prepaired. Several testes were carried to get the porcelain propetrties. They were apparent density, apparent porosity, percentage of absorbed water, and hydraulic conductivity. Tests results of these properties showed that the addining of remnants of the membership has big effect on the porcelain properties and the changes of these properties depend on the amount of these additives in the porcelain body. As a result for these changes the amount of water which could be filtered by them would be increased respectly. These filters were compatible with important filter standard specifications

such as toxicity test and suspended particles. The results showed that the filtered water were conformity with the specifications for public drinking water with high flow rates.
\end{abstract}

Key words: filter, Limestone, Montmorolinite clays, porcelain, Sand, and remnants of the membership.

\section{Introduction}

Increasing importance of healthy drinking water which contain low ratios of impurities with population growth, which is usually accompanied by a scarcity of drinking water due to environmental degradation caused by industrial development and its different contaminations. As well as the waters of the rivers in the provinces of dry and semi-dry and that Iraq is part of it, characterized by high turbidity in some seasons of the year. In order to preserve human health and the environment many types of filters were made to remove turbidity or smell and taste, or turbidity, taste and smell. Candidate porcelain filters are concidered of the most important domestic water filters [1], and most common for easy manufacturing and mandated quality properties, where by means of them can get rid of plankton sizes up to parts of micron[2, and 3].

Muds are the raw material in the porcelain industry, where $60 \%$ of these muds in the world exploited in such industries. Montmorolinite clays are one of these muds [4], and it has properties for adsorption and exchanging cations [5]. In addition to muds other materials are used to improve the specifications of the product, as needed, and that the multiplicity of the use of these filters. And of these additives are sand, limestone plus some remnants of the membership ( organic matter) such as wood remains, grain husks, such as husks of wheat, barley, corn ... etc [6], and leaven fermented materials, [7, 8].

Purpose of this study is to purify the water of pollutants using porcelain filters made of locally available raw materials and with special specifications make the candidate with high efficiency in the speed and quality of the filtered water.

\section{Proceeding method}

Using antipersonnel three key raw materials in the manufacture of porcelain water filter, namely: Montmorilonite, Sand, Limestone, and proportion of organic matter. The raw materials were cleaned, washed with distled water, and dried for $24 \mathrm{hr}$. at $110 \mathrm{C}^{\circ}$. Then these materials were grained to same size less than 65 $\mu \mathrm{m}$, to get porous porcelain [9]. The mixing weight ratios of these materials were shown in "Table 1". The materials has been mixed by using electric mixing mashine and confused for 30 minutes.

Table1: Details ofthe mixtures used to produce porcelain filters.

\begin{tabular}{|l|l|l|}
\hline Mix No. & \% Montmorolinite + \%Sand + \% Limestone & \% Organic matters \\
\hline 1 & $50 \% \mathbf{M}+25 \% \mathbf{S}+25 \% \mathbf{L}$ & 0 \\
\hline 2 & $90 \%(50 \% \mathbf{M}+25 \% \mathbf{S}+25 \% \mathbf{L})$ & 10 \\
\hline 3 & $85 \%(50 \% \mathbf{M}+25 \% \mathbf{S}+25 \% \mathbf{L})$ & 15 \\
\hline 4 & $80 \%(50 \% \mathbf{M}+25 \% \mathbf{S}+25 \% \mathbf{L})$ & 20 \\
\hline
\end{tabular}

To prepare the dough of porcelain to be molded in mechanical extrusion method, suitable amount of about 5-6 kg of each prepared mixture should be taken and then placed in a glass jar with a tight lid, then be 
submerged in water to ensure arent water molecules and surround grains[10]. The dough would be placed in extrusion mechanical template machine to provide cylindrical shape. The required dimensions of cylinder were: outer diameter of $50 \mathrm{~mm}$, inner diameter $40 \mathrm{~mm}$, and height $250 \mathrm{~mm}$. As shown in "Fig.1".

To test the effect of the proportion of organic material in the porcelain mixture on the properties of candidate porcelain has been prepared blends with four different proportions of organic materials $(0 \%, 10 \%$, $15 \%$, and $20 \%$ ).

After the formation of the samples dried in a thermal oven at $110 \mathrm{C}^{\circ}$ for 48 hours [11]. Then burned in a mufel furnace to $1200 \mathrm{C}^{\circ}$ [12]. And upon completion of the burn for all models conducted post-burn tests were carried out. They were: apparent density, porosity, water absorption, hydraulic conductivity, toxicity screening and intercept suspended solids, which are considered very important in determining the efficiency of candidate porcelain water.

\section{Results and discussion}

The samples that have been prepared by mechanical extrusion characterized quality, cohesion, flat surfaces and edges, straightening rims and lack of curvature after drying. The use of electrostatic discharge (vacum) when shaped the porcelain by mechanical extrusion helped to get rid of air trapped in the dough and get a suitable porous. These porous help the fumes and gases generated during drying and burning to leave the porclain safely without leading to crak and explose the samples [13,and 14].

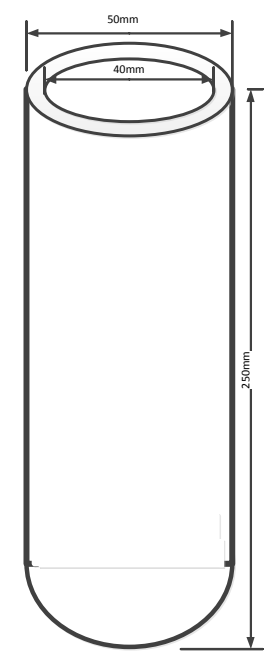

Fig. 1: General view of cylindrical porcelain filter.

The samples had low shrinking, less than $5.3 \%$ and that may be due to the high proportion of nonelastomeric materials Sand and Limestone in the models, which lead to reduced water formation [15].

Values of reached apparent densities of models for porcelain filters were: $(1.4,1.36$, 1.29, and1.04) $\mathrm{gm} / \mathrm{cm}^{3}$ respectively. The density decrease, as showen in "Fig. 2", is attributable to increase the proportion of organic material to the effect of liberalizing gas accompanied by weight loss quantities of the sample, as well as due to the decomposition of calcium carbonate and liberate carbon dioxide gas [16, and 17].

Apparent porosity and water absorption are the most important properties of the porcelain water filters, which indicates the proportion of open pores, that depend on these two special two important factors, namely: (i)The process of configuring tract and gaps because of the gases liberated, and (ii) attic felting. And these two factors are affected by the temperature incineration, chemical and mineral kunas, and the proportion of organic matter in the paste porcelain body [10, and 18]. "Figs. 3 and 4" showed increasing in apparent porosity and water absorption when increasing in the proportion of organic material in the porcelain paste. The amount of glass phase due to the sintering process is not sufficient to full tracks and gaps and thereby increasing the porosity of the product, which in turn raised the percentage of water absorption and apparent porosity[18]. The high porocity caused high hydraulic conductivity of porcelain samples. Which were: $(0.0015,0.005,0.0104$, and $0.08) \mathrm{m} / \mathrm{hr}$ respectively, as shown in "Fig. 5". That caused high rates of flow through filters. At $2.0 \mathrm{~m}$ head of water the flow rates frome the filters were: $(25,85,175$, and 1390$) \mathrm{l} / \mathrm{hr}$ respectively. Which means increament of flow by (3 to 52)times. These values are considered excellent, by which energy and money could be saved, and using these filters for other purposes. 
The high ability of porcelain filters for the filtration turns to severe (aliasing) in the gaps occurring due to escape of gases during the burning process [18], thereby hindering the movement of suspended solids in the water during its entry into the gaps in the candidate porcelain.

It appears from "Table 2" comparision to some of the physical and chemical properties of the porcelain water filters with safe drinking water and according to the World Health Organization(WHO) [19], and the Iraqi specification No. 417 for the year 1986 [ 20]. It was found that the water filtered by porcelain was safe for drinking with high specifications, especially for solid materials and outstanding, their concentrations amounted to zero in water emerging from the candidate porcelain. Noted from the previous results that the filter No.4, which was manufactured with $20 \%$ organic matter is the best and that nominated the highest amount of water with matching specifications for potable water.

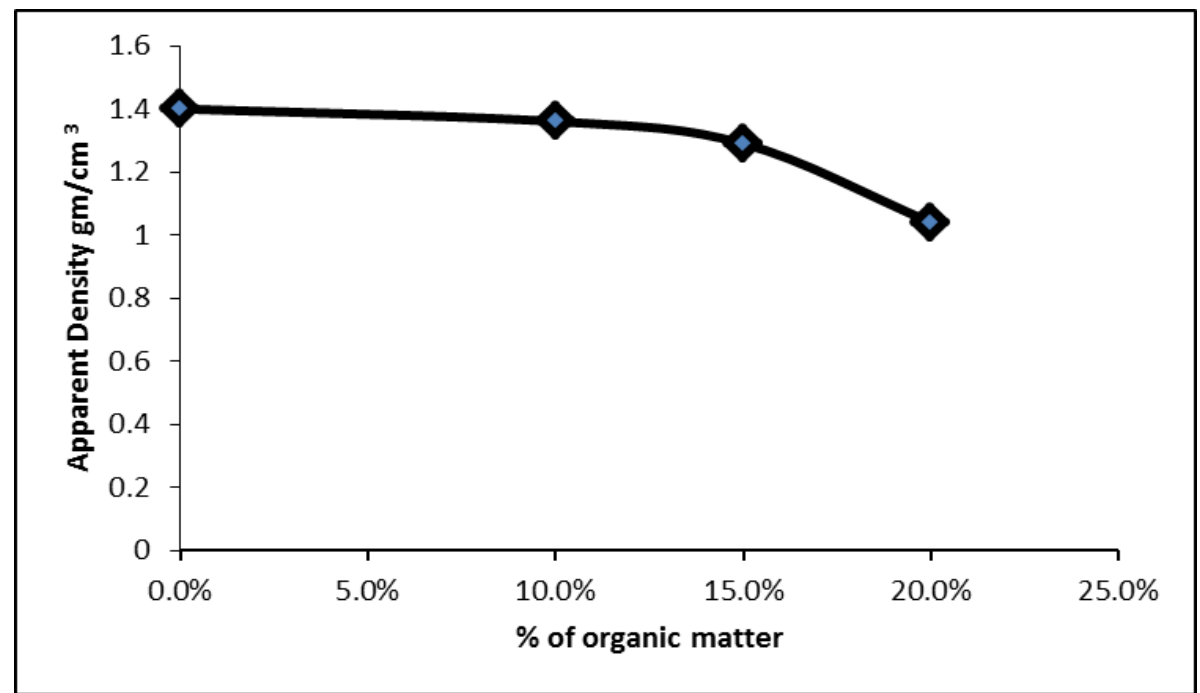

Fig 2: Apparent density change with the percentage of organic matter.

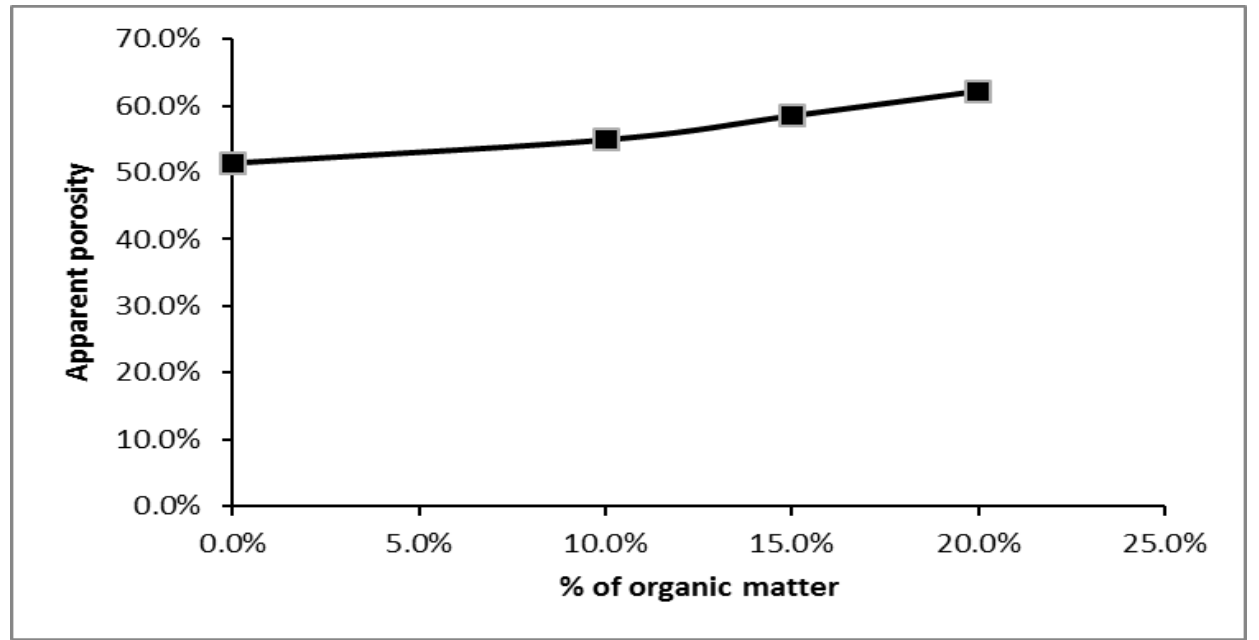

Fig 3: Apparent porosity change with the percentage of organic matter. 


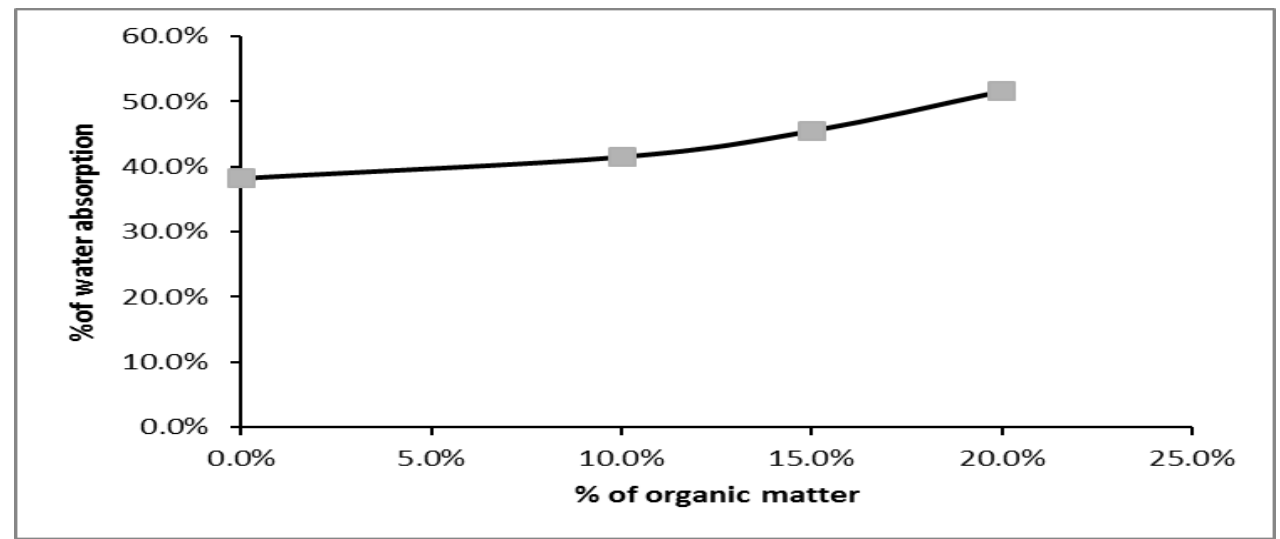

Fig 4: percentage of water absorption change with the percentage of organic matter.

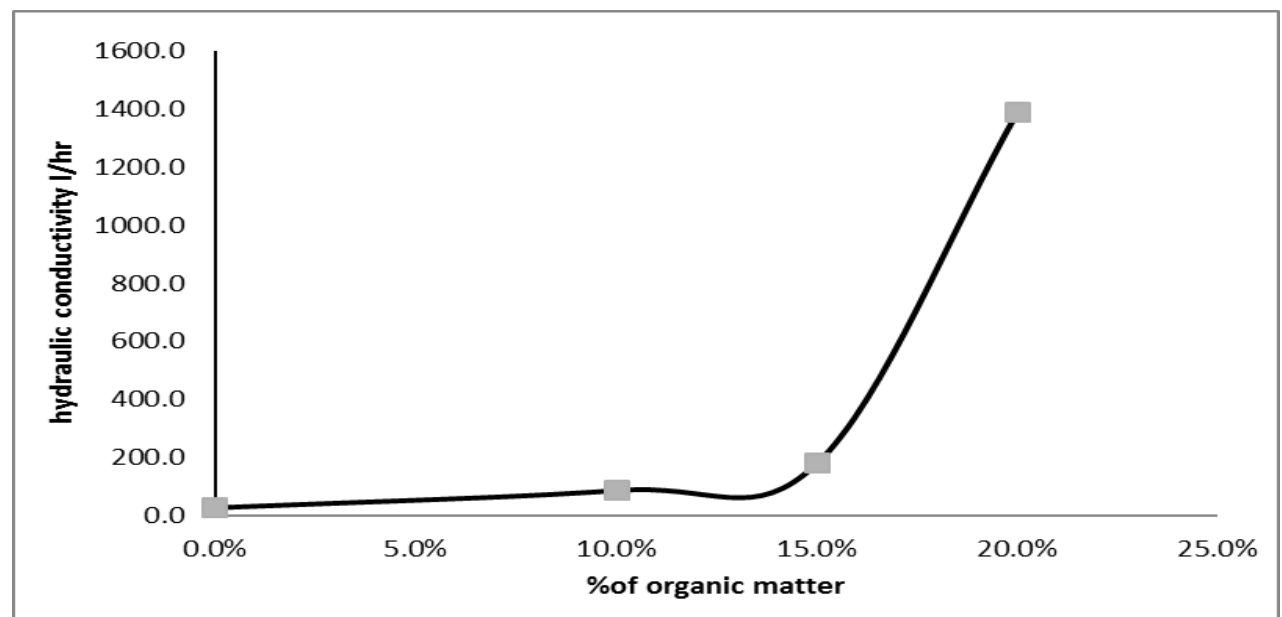

Fig 5: hydraulic conductivity (m/hr) change with the percentage of organic matter.

Table 2: Compared to the physical and chemical properties of the porcelain filters water produced with the specifications of the Iraqi and the World Organization for Global Drinking Water (WHO).

\begin{tabular}{|c|c|c|c|c|c|c|c|}
\hline $\begin{array}{l}\text { Physical and } \\
\text { chemical } \\
\text { properties }\end{array}$ & $\begin{array}{l}\text { Raw } \\
\text { water }\end{array}$ & $\begin{array}{l}\text { Water } \\
\text { passed } \\
\text { filter } \\
\text { no.1 }\end{array}$ & $\begin{array}{l}\text { Water } \\
\text { passed } \\
\text { filter no.2 }\end{array}$ & $\begin{array}{l}\text { Water } \\
\text { passed } \\
\text { filter no.3 }\end{array}$ & $\begin{array}{l}\text { Water } \\
\text { passed } \\
\text { filter no.4 }\end{array}$ & $\begin{array}{l}\text { Iraqi } \\
\text { specifications }\end{array}$ & $\begin{array}{l}\text { WHO } \\
\text { specifications }\end{array}$ \\
\hline Turbidity(NTU) & 115 & 0 & 0.01 & 0.03 & 0.05 & $<10$ & $<1$ \\
\hline $\mathrm{Ca}^{+2}(\mathrm{mg} / \mathrm{l})$ & 640 & 120 & 135 & 180 & 387 & 500 & 500 \\
\hline $\mathrm{NO}_{3}^{-1}(\mathrm{mg} / \mathrm{l})$ & 7.4 & 0.29 & 0.8 & 2.25 & 4.9 & 45 & 45 \\
\hline $\mathrm{SO}_{4}{ }^{-2}(\mathrm{mg} / \mathrm{l})$ & 732 & 143 & 246 & 355 & 387 & 400 & 400 \\
\hline $\mathrm{Cl}^{-}(\mathrm{mg} / \mathrm{l})$ & 286 & 27 & 45 & 88 & 140 & $200-600$ & 250 \\
\hline $\mathrm{Pb}^{+2}(\mathrm{mg} / \mathrm{l})$ & 0.4 & 0.0 & 0.0 & 0.0 & 0.0 & 0.05 & 0.05 \\
\hline $\mathrm{Cd}^{+2}(\mathrm{mg} / \mathrm{l})$ & 0.05 & 0.0 & 0.0 & 0.0 & 0.0 & 0.005 & 0.005 \\
\hline $\mathrm{Zn}^{+2}(\mathrm{mg} / \mathrm{l})$ & 6.3 & 0.041 & 0.32 & 0.73 & 0.88 & 5.0 & 1.0 \\
\hline $\mathrm{Mn}^{+2}(\mathrm{mg} / \mathrm{l})$ & 3.7 & 0.005 & 0.027 & 0.043 & 0.083 & 0.1 & 0.1 \\
\hline $\mathrm{Cu}^{+2}(\mathrm{mg} / \mathrm{l})$ & 0.99 & 0.0 & 0.0 & 0.0 & 0.0 & 0.5 & 0.5 \\
\hline
\end{tabular}

\section{Refferences}

[1]. Franz, Amber, Aperformance study of ceramic candle filters in Kenya including tests for Coliphage removal, master degree, University of North Carolina Masschusetts Institute of Technology, Chapel Hill, 2005

[2]. Bielefeldt, Angela R., Summers, R. Scott, Kohler, Amanda, and Kowalski, Kate, Bacteria and virus removal in point-of-use ceramic water filters, International Ceramic Pot Filter Workshop, Atlanta, WEF Disinfection 2009, 27- 29.

[3]. Bielefeldt, Angela R., Summers, R. Scott, Kohler, Amanda, and Kowalski, Kate, Bacterial treatment effectiveness of point-of-use ceramic water filters, Journal of Water Research, 4 3, $2009,3559-3565$.

[4]. 1a. Eva Martin del Valle, Miguel A. Galan Serrano, and Ramon L. Cerro, Use of Ceramic Monoliths as Stationary Phase in Affinity hromatography, Journal of Biotechnol. Prog. 19, 2003, 921-927.

[5]. Al-Bassam, Khaldoun S., Abdul Rahman, Shaima'a M., and Rashid, Sallama Ch., Cation Exchange Capacity in Iraqi Industrial Montmorillonitic Claystones and Their Use in the Estimation of Montmorillionite Content in the Produced Clay, Jour. Geol.Soc. Iraq,7 (3), 2011, 1- 17.

[6]. Kartini, K., Mahmud, H.B., Hamidah, M.S., Absorption and permeability performance of selangor rice husk ash blended grade 30 concrete, Journal of Engineering Science and Technology, 5, (1), 2010, 1 - 16. 
[7]. Siddique, R., Utilization of wood ash in concrete manufacturing, Journal of Resources, Conservation \& Recycling, 67 (09213449), 2012, 27-33 .

[8]. Masitah, H., Bassim, H. H., Latif, A. A., Zulfakar, M., Naimah, I., and Salwa, M.Z.M., Low cost removal of reactive orange 16 dye using cross-linked chitosan/ oil palm ash composite beads, Journal of Applied Sciences, 11(13),2011,2292-2298.

[9]. Albadry, A.H.S., Scientific technic for porcelain Art (1.st Part :Clay, Al-yarmuke University, $1^{\text {st }}$ edition, 2000).

[10]. Hamilton, D., Manual of pottery and porcelains (Thames and Hilton Ltd., London. Printed in Hong Kong. ISBN O500 68007 8, 1982).

[11]. Barsaum, M. W., Fundament of porcelain ( Series in Materials Science and Engineering, Series Editors: B Cantor, Department of Materials,University of Oxford, UK, M J Goringe, School of Mechanical and Materials Engineering,University of Surrey, UK, 2003).

[12]. Tamer-Agha, M.Y., and, Effach, A.H., Manufacturing porcelain water filters from Iraqi kaolinite" Iraqi Journal of Science, No.3, 2000 .

[13]. Robison, G. C., Extrusion defects in: Onada and Hench, L. (eds) Porcelain processing befor firing (John Wiley and Sons Pub, NewYork, 1981).

[14]. Serry, M.A., and Hanna, S., Composition and properties of some dolomite zirconia refractories" Trans.Br.Ceramic, Soc.Vol.78, No.3, 1979.

[15]. Mohamed, S. N. D., Assessment of utilization of gypsum and clay from the Fatha formation in Darband Bazian area in manufacturing of thermal insulators, College of Science, Baghdad University, Iraq, 2005.

[16]. Rice, Roy W., Ceramic fabrication technology (Marcel Dekker, Inc.New York, 2003).

[17]. Rayon, W., Properties of ceramic raw materials (2 ${ }^{\text {nd }}$ edition, Pergamon Press, Oxford, 1978).

[18]. Peters, T. and Iberg, R., Mineralogical changes during firing of calcium-rich clays." Ceram. Bull., 57, 1982.

[19]. WHO(World Health Organization), WHO guidelines for drinking water quality" $3^{\text {rd }}$ edition. Geneva: World Health Organization, 2006.

[20]. ASTM C373 -88, Standard test method for water absorption, bulk density, apparent porosity, and apparent specific gravity of fired whiteware products" http//:www.astm.org/Standards/C 